\title{
Urgensi Beracara Di Pengadilan Perdata Terhadap Hukum Acara Perdata
}

\author{
Oyaldi Puhi', Rustam Hs Akili'2, Ibrahim Ahmad'3, Roy Marthen Moonti4, \\ Muten Nuna5. \\ 1,2,3,4,5 Ilmu Hukum, Fakultas Hukum, Universitas Gorontalo \\ Email Correspondensi: roymoonti16@gmail.com \\ No. Handphone Correspondensi : (+62) 8114313222
}

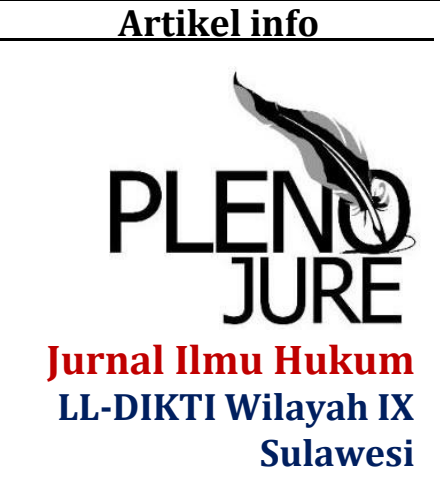

Artikel history:
Received; 30-03-2021
Revised:22-04-2021
Accepted;23-04-2021

\begin{abstract}
Abstrak. Hukum acara perdata merupakan hukum perdata formil, yang pada dasarnya berfungsi mempertahankan atau menegakkan hukum perdata materiil melalui pengadilan apabila terjadi pelanggaran terhadap hukum perdata materiil atau terjadi sengketa. Bahkan hukum acara perdata juga mengatur bagaimana tata cara memperoleh hak dan kepastian hukum manakala tidak terjadi sengketa melalui pengajuan "permohonan" ke pengadilan. Artikel ini ingin menjelaskan bagaimana mekanisme beracara di pengadilan perdata terhadap hukum acara perdata, dengan menggunakan metode penulisan secara normatif. Sebagai kesimpulan, artikel ini menjelaskan bahwa didalam beracara hukum acara perdata dapat ditinjau dalam dua aspek yakni dalam arti luas dan dalam arti sempit, dalam arti luas beracara meliputi segala tindakan hukum yang dilakukan, baik di luar maupun di dalam persidangan di pengadilan guna menyelesaikan suatu perkara menurut ketentuan hukum acara perdata. Sedangkan dalam arti sempit, beracara meliputi tindakan beracara di dalam persidang di pengadilan dari sidang pertama sampai dengan hakim menjatuhkan putusannya. Sedangkan untuk prosedur dalam pengajuan Gugatan di Pengadilan merujuk pada Pasal 118 ayat (1) Herizen Indlandsch Reglement ("HIR")/Pasal 142 RBg.
\end{abstract}

Abstract. Civil procedural law is formal civil law which basically is to defend or enforce material civil law through the court if there is a violation of the law toward material civil law or a dispute. Even the civil procedural law also regulates how to obtain legal rights and certainty, if there is no dispute through filing an "application" to the court. This article aims to explain how the procedure of mechanisms in civil courts toward civil procedural law by using the normative writing method. In conclusion, this article explains that civil procedural law proceedings can be viewed in two aspects, which are broad sense and narrow sense. In the broad sense, it includes all legal actions that are taken both outside and inside the court to resolve the case according to the provisions of civil procedural law. Whereas in a narrow sense, it includes proceeding at trial in court from the first trial until the judge makes his decision. whereas, the procedure for filing a lawsuit 
in court is referring to Article 118 paragraph (1) Herizen Indlandsch Reglement ("HIR") / Article 142 RBg.

\section{Keywords:}

Hukum Acara perdata;

Praktik Peradilan

Perdata; Penyelesaian

Sengketa; Perdata;.

\section{PENDAHULUAN}

Negara Indonesia merupakan negara kesatuan yang berlandaskan Hukum (Rechtstaat) dan bukan berdasarkan Kekuasaan (Machstaat) yang bertujuan untuk mengatur kehidupan berbangsa dan bernegara, Hukum merupakan pemimpin dan hukum juga tidak terlepas dari yang namanya demokrasi, maka dari kedemokrasian itu keadilan mampu diwujudkan. UUD 1945 merupakan konsep negara hukum indonesia yang didalamnya terdapat nilai-nilai sosial budaya Indonesia dan merupakan jantung pergerakan bagi Indonesia karena tanpa itu arah dan tujuan negara tercinta menjadi tidak jelas dan kata perkata di dalamnya di rancang dan diterbitkan dengan makna yang sangat mendalam. ${ }^{1}$ Negara hukum merupakan konsep bernegara yang telah berkembang dari beberapa dekade lalu. Terbukti dari keberadaan pemikiran mengenai konsepkonsep negara hukum yang telah ada dan berkembang jauh sebelum konsep negara hukum telah tersusun dan tertata seperti saat sekarang ini. ${ }^{2}$

HIR (Herziene Inlandsch Reglemen) merupakan salah satu sumber hukum acara perdata utama peninggalan kolonial Hindia Belanda yang masih berlaku di negara kita hingga kini. HIR sebenarnya berasal dari Inlandsch Reglement (IR) atau Reglement Bumiputera, yang termuat dalam Stb. 1848 Nomor 16 dengan judul (selengkapnya) "Reglement op de uit oefening van de politie de Burgerlijke Rechtspleging en de strafvordering onder de Wanders en de Vreemde Oosterlingen op Java en Madura" (Reglement tentang pelaksanaan tugas kepolisian, peradilan perkara perdata dan penuntutan perkara pidana terhadap golongan Bumiputera dan Timur Asing di Jawa dan Madura). Inlandsch Reglement selanjutnya disingkat IR pertama kali diundangkan tanggal 5 April 1848 (Stb. 1848 Nomor 16) merupakan hasil rancangan JHR. Mr. HL. Wichers, President Hoogge Rechtshof (Ketua Pengadilan Tertinggi di Indonesia pada zaman Hindia Belanda) di Batavia. Selain HIR sebagai sumber utama hukum acara perdata dikenal pula Rbg (Rechtsreglement voor de Buitengewesten) Berlaku untuk daerah seberang yang merupakan singkatan pula dari "Reglement tot Regeling van het Rechtswezen in de Qewesten buiten Java en Madura", suatu ordonansi yang dibuat Gubernur Jenderal Hindia Belanda pada tanggal 11 Mei 1927 (Stb.

\footnotetext{
${ }^{1}$ Asfiyak, K., \& Muslim, M. (2020). Praktek Sidang Cepat Di Luar Aturan Hukum Acara Perdata Demi Efisiensi Penyelesaian Perkara Di Pengadilan Agama Kota Malang. Jurnal Ilmiah Ahwal Syakhshiyyah (JAS), 2(2), 44-51, Hal. 46.

${ }^{2}$ Nuna, M., \& Moonti, R. M. (2019). Kebebasan Hak Sosial-Politik Dan Partisipasi Warga Negara Dalam Sistem Demokrasi Di Indonesia. Jurnal Ius Constituendum, 4(2), 110-127. Hal. 112.
} 
1927 Nomor 227). ${ }^{3}$

Menurut fungsinya, hukum dibedakan menjadi hukum materiil dan hukum formil atau hukum acara. Hukum acara perdata adalah hukum perdata formil, yang pada dasarnya berfungsi mempertahankan atau menegakkan hukum perdata materiil melalui pengadilan apabila terjadi pelanggaran terhadap hukum perdata materiil atau terjadi sengketa. Bahkan hukum acara perdata juga mengatur bagaimana tata cara memperolah hak dan kepastian hukum manakala tidak terjadi sengketa melalui pengajuan "permohonan" ke pengadilan. Namun demikian, secara umum hukum acara perdata mengatur proses penyelesaian perkara perdata melalui hakim di pengadilan penyusunan gugatan, pengajuan gugatan, pemeriksaan gugatan, putusan pengadilan sampai dengan eksekusi atau pelaksanaan putusan pengadilan. ${ }^{4}$

Hukum acara perdata atau yang sering juga disebut hukum perdata formal adalah sekumpulan peraturan yang membuat bagaimana caranya orang bertindak di depan pengadilan, bagaimana caranya pihak yang terserang kepentinganya mempertahankan diri, bagaimana hakim bertindak sekaligus memutus perkara dengan adil, bagaimana melaksanakan keputusan hakim yang bertujuan agar hak dan kewajiban yang telah diatur dalam hukum perdata materiil itu dapat berjalan dengan semestinya, ${ }^{5}$ sehingga terwujud tegaknya hukum dan keadilan.

Para sarjana hukum menyatakan bahwa hukum acara perdata adalah rangkaian peraturan-peraturan yang memuat cara bagaimana orang harus bertindak terhadap dan di muka pengadilan dan cara bagaimana pengadilan itu harus bertindak, satu sama lain untuk melaksanakan berjalannya peraturanperaturan hukum perdata. Pada pendapat ahli hukum lainnya menyatakan bahwa hukum acara itu mengabdi kepada hukum materiil, maka dengan sendirinya setiap perkembangan dalam hukum materiil itu sebaiknya selalu diikuti dengan penyesuaian hukum acaranya, dan hukum acara perdata ialah peraturan hukum yang mengatur proses penyelesaian perkara perdata lewat hakim (pengadilan) sejak dimajukannya gugatan sampai dengan pelaksanaan keputusan hakim. ${ }^{6}$

Dengan demikian kedudukan hukum acara perdata menjadi amat penting, beberapa alasan yang dikemukan mengenai pentingnya pengaturan hukum acara perdata antara lain: pertama, menjamin kepastian hukum di mana setiap orang berhak mempertahankan hak perdatanya sebaik-baiknya dan setiap orang yang melakukan pelanggaran terhadap hukum perdata yang mengakibatkan kerugian pada orang lain dapat dituntut melalui pengadilan. Kedua, hukum acara perdata berfungsi untuk menegakkan, mempertahankan dan menjamin ditaatinya ketentuan hukum materiil dalam praktik melalui perantaraan peradilan. ${ }^{7}$ Adapun permasalahan yang diangkat dalam penulisan ini yakni mengetahui Mekanisme Beracara di Pengadilan Perdata Terhadap Hukum Acara Perdata.

\footnotetext{
${ }^{3}$ Machmud, S. (2019). Konsep Strict Liability dalam Hukum Acara Perdata Indonesia. Jurnal Hukum Media Justitia Nusantara, 7(1). Hal, 44

${ }^{4}$ Nyoman A. Martana, (2016). Hukum Acara Dan Praktek Peradilan Perdata, Fakultas Hukum Udayana. Hal. 2.

${ }^{5}$ Hamzah, Y. A., Mangarengi, A. A., \& Buana, A. P. (2020). Analisis Yuridis Perkawinan Dibawah Umur Melalui

Kewenangan Kantor Urusan Agama (Studi Kasus di KUA Kabupaten Bantaeng). PLENO JURE, 9(2), 119-128.

${ }^{6}$ M Rasyid, L., \& Herinawati, H. (2015). Hukum Acara Perdata. Unimal Press. Hal. 10-11.

7 Dwi Agustine (2017). Pembaharuan Sistem Hukum Acara Perdata. Jurnal RechtsVinding, 6(1), 1-7. Hal. 1
} 


\section{METODE}

Penulisan yang digunakan dalam artikel ini yakni metode penulisan hukum secara normatif. dan bersifat deskriptif. Pendekatan penelitian secara normatif dengan menelaah hukum positif dan bahan-bahan hukum lainnya yang termasuk sumber-sumber hukum, serta bahan hukum sekunder untuk melengkapi referensi bagi hasil kajian ini. Teknik yang digunakan oleh penulis untuk menghasilkan luaran hasil penelitian melalui studi kepustakaan. Pemanfaatan bahan-bahan hukum dalam metode penelitian secara normatif untuk menjawab permasalahan, melalui pengelolaan bahan-bahan hukum, hingga dapat menyimpulkan dari hasil analisis secara koheren, melalui susunan bahan hukum yang diinventarisir secara relevan dan sistematis.

\section{HASIL DAN PEMBAHASAN}

Kehidupan sehari-hari orang sering menyebut perkara apabila menghadapi persoalan yang tidak dapat diselesaikan antara pihak-pihak. Untuk mengatasinya mereka minta penyelesaian melalui pengadilan. Apabila seseorang mengajukan permohonan kepada pengadilan agar pemohon ditetapkan sebagai pemilik barang, ahli waris, wali, pengangkat anak dikatakan bukan perkara karena tidak ada yang diselisihkan. Pengertian yang demikian ini sebenarnya tidak tepat. Perlu dibedakan antara perkara dan sengketa. Pengertian perkara lebih luas daripada pengertian sengketa. Sengketa itu sebagian dari perkara, sedangkan perkara itu belum tentu sengketa. Dalam pengertian perkara tersimpul dua keadaan, yaitu ada perselisihan dan tidak ada perselisihan.

Ada perselisihan artinya ada sesuatu yang menjadi pokok perselisihan, ada yang dipertengkarkan, ada yang disengketakan. Perselisihan atau persengketaaan itu tidak dapat diselesaikan oleh pihak-pihak sendiri, melainkan memerlukan penyelesaian melalui pengadilan sebagai instansi yang berwenang dan tidak memihak. Tugas hakim adalah menyelesaikan sengketa dengan adil, dengan mengadili pihak-pihak yang bersengketa dalam sidang pengadilan dan kemudian memberikan putusannya. Tugas hakim demikian ini termasuk dalam Jurisdictio Contentiosa artinya kewenangan mengadili dalam arti yang sebenarnya untuk memberikan suatu putusan keadilan dalam suatu sengketa.

Hakim dalam menjalankan tugas berdasarkan Jurisdictio Contentiosa harus bersifat bebas dari pengaruh atau tekanan dari pihak manapun (independent Justice). Tidak ada perselisihan artinya tidak ada yang diperselisihkan, tidak ada yang disengketakan. Pihak yang bersangkutan tidak minta peradilan atau putusan dari hakim, melainkan minta ketetapan dari hakim tentang status sesuatu hal, sehingga mendapat kepastian hukum yang wajib dihormati dan diakui oleh semua orang. Contohnya adalah permohonan untuk ditetapkan sebagai ahli waris yang sah, permohonan tentang pengangkatan anak. Tugas hakim yang demikian ini termasuk Jurisdictio Voluntaria artinya kewenangan memeriksa perkara yang tidak bersifat mengadili, melainkan bersifat administratif saja. Dalam hal ini hakim bertugas sebagai pejabat administrasi negara untuk mengatur suatu hal.

Beracara dalam hukum acara perdata dapat dipakai dalam arti luas dan 
dalam arti sempit. Dalam arti luas beracara meliputi segala tindakan hukum yang dilakukan, baik di luar maupun di dalam sidang pengadilan guna menyelesaikan suatu perkara menurut ketentuan hukum acara perdata. Tindakan hukum tersebut meliputi tindakan persiapan, tindakan beracara sesungguhnya di dalam sidang pengadilan. Dalam arti sempit, beracara meliputi tindakan beracara sesungguhnya di dalam sidang pengadilan sejak sidang pertama sampai dengan sidang terakhir hakim menjatuhkan putusannya. ${ }^{8}$

Mekanisme pengajuan surat gugatan di Peradilan Perdata.

1. Pendaftaran surat gugatan

2. Jawaban dari tergugat

3. Replik Adalah jawaban balasan atas jawaban tergugat

4. Duplik adalah jawaban tergugat atas replik penggugat yang intinya membantah dalil-dalil penggugat dalam repliknya serta menguatkan kembali dalil-dalil tergugat dalam jawabannya

5. Pembuktian.

Alat-alat bukti dalam perkara perdata terdiri atas :

a. Bukti tulisan;

b. Bukti dengan saksi-saksi;

c. Persangkaan-persangkaan;

d. Pengakuan; dan

e. Sumpah.

6. Kesimpulan adalah kesimpulan-kesimpulan yang dibuat masing-masing pihak sesudah terjadinya jawab menjawab dan pembuktian sehinga akhirnya dapat diambil suatu kesimpulan.

7. Putusan hakim putusan hakim dapat berupa:

a. Menerima gugatan;

b. Menolak gugatan; dan

c. Tidak diterimanya gugatan.

8. Dokumen perlu dipersiapkan ketika akan mengajukan gugatan perceraian:
a. Gugatan;
b. Surat nikah;
c. KTP (kartu tanda penduduk);
d. KK (kartu keluarga);
e. Akte lahir anak-anak; dan
f. Surat-surat berharga jika punya.

Gugatan adalah suatu tuntutan hak yang diajukan oleh penggugat kepada tergugat melalui pengadilan. Gugatan dalam hukum acara perdata umumnya terdapat 2 (dua) pihak atau lebih, yaitu antara pihak penggugat dan tergugat, yang mana terjadinya gugatan umumnya pihak tergugat telah melakukan pelanggaran terhadap hak dan kewajiban yang merugikan pihak tergugat.Terjadinya gugatan umumnya setelah pihak tergugat melakukan pelanggaran hak dan kewajiban yang merugikan pihak penggugat, tidak mau secara sukarela memenuhi hak dan kewajiban yang diminta oleh pihak penggugat, sehingga akan timbul sengketa antara penggugat dan tergugat. Sengketa yang dihadapi oleh para pihak apabila tidak diselesaikan oleh para

${ }^{8}$ Laila M. Rasyid, Op.Cit, Hal. 20-22. 
pihak melalui persidangan pengadilan untuk mendapatkan keadilan. Suatu gugatan yang diajukan oleh penggugat agar dapat diterima oleh pengadilan haruslah mempunyai alasan-alasan yang kuat, yang mana salah satu alasan yang harus dipenuhi adalah adanya pelanggaran hak dan telah merugikan penggugat. Apabila dalam gugatan yang diajukan oleh penggugat ke pengadilan tidak mempunyai alasan-alasan yang kuat tentang terjadinya peristiwa, maka gugatannya dalam persidangan akan berakibat dinyatakan tidak dikabulkan oleh hakim yang memeriksa perkaranya.

Suatu gugatan yang diajukan oleh penggugat agar dapat diterima oleh pengadilan haruslah memenuhi syarat-syarat dan atau ketentuanketentuan yang ada dalam HIR maupun RBg. Adapun syarat-syarat dan atau ketentuan-ketentuan antara lain sebagai berikut.

1. Syarat sahnya suatu surat gugatan :

a. Syarat Formal pada umumnya syarat formal yang harus dipenuhi dalam suatu gugatan adalah; Tempat dan Tinggal Pembuatan Surat Gugatan; Materai; Tanda Tangan.

b. Syarat Substansial, terdiri dari; Identitas Para Pihak yang Berperkara; Identitas Kuasa Hukum dan Domisili. ${ }^{9}$

\section{Posita (Fundamentum Petendi)}

Adalah dalil-dalil konkret tentang adanya hubungan yang menjadi dasar pengajuan suatu gugatan perdata.Posita ini secara garis besar terbagi atas 2 bagian yaitu:

a. Urian tentang kejadian yang merupakan penjelasan tentang duduknya perkara.

b. Uraian tentang hukum yang merupakan penjelasan tentang hubungan hukum sebagai dasar yuridis pengajuan suatu gugatan perdata. Singkatnya suatu posita harus menguaraikan objek, perkara, fakta-faktanya hukum kualifikasi perbuatan tergugat.

Petitum/tuntutan adalah apa yang diminta oleh penggugat atau yang diharapkan diputuskan oleh hakim. Petitum biasanya terdiri dari dua bagian, yaitu Petitum Primair yang berisikan halhal pokok yang mohon dikabulkan oleh pengadilan dan Petitum Subsidair yang isinya memberi kebebasan kepada Hakim untuk mengabulkan lain dari Petitum Primair.

Pembuktian Dalam Perkara Perdata ialah meyakinkan Hakim terhadap kebenaran atau dalil-dalil yang dikemukakan dalam suatu sengketa. Dengan demikian nampaklah bahwa pembuktian itu hanyalah diperlukan dalam persengketaan atau "perkara" di muka Hakim atau Pengadilan. Membuktikan itu hanya diperlukan, apabila timbul suatu perselisihan. Jika tidak ada orang yang menyangkal hak milik saya atas rumah yang saya diami, maka saya tidak perlu membuktikan bahwa rumah itu milik saya. Jika sipenjual barang tidak menyangkal bahwa sipembeli sudah membayar harga barang yang dibeli dan telah diterimanya, maka pembeli itu tidak perlu membuktikan bahwa itu sudah membayar harga barang tadi. Jika hak waris seorang anak angkat atau barang

${ }^{9}$ Dinata, I. W. W., \& Bagiastra, I. N. Cara Mengajukan Gugatan Dan Perubahan Gugatan Dalam Praktek Peradilan Hukum Acara Perdata. Kertha Negara: Journal Ilmu Hukum, 5(2). Hal. 2 
peninggalan bapak angkatnya, tidak dibantah oleh suatu pihak, maka ia tidak perlu membuktikan hak warisannya tersebut. ${ }^{10}$

Dalam hal membuktikan suatu peristiwa pada acara perdata ada beberapa cara yang ditempuh. Tidak semua peristiwa dapat diajukan dihadapan Hakim di persidangan, agar Hakim dapat secara langsung melihatnya dengan mata kepala sendiri. Apabila suatu peristiwa yang akan dibuktikan itu tidak mungkin dihadapkan di muka persidangan atau peristiwa tersebut termasuk dalam masa lampau, sehingga secara langsung tidak dapat dilihat atau didengar olek Hakim, Maka penggugat dapat menunjukkan alat-alat bukti lain yang dapat dijadikan alat bukti sah di muka Hakim.

Ketidakpastian hukum (recutsonzakerheid) dan kesewenang-wenangan (willekkeur) akan timbul apabila hakim, dalam melaksanakan tugasnya itu, diperbolehkan menyandarkan putusannya atas keyakinannya, biarpun itu sangat kuat dan sangat murni. Keyakinan hakim itu harus didasarkan pada sesuatu yang oleh undang-undang dinamakan alat bukti. Dengan alat bukti ini masing-masing pihak berusaha membuktikan dalilnya atau pendiriannya yang dikemukakannya kepada hakim yang diwajibkan memutus perkara mereka itu. Dalam pada itu harus di indahkan juga aturan-aturan yang menjamin keseimbangan dalam pembebanan kewajiban untuk membuktikan hal-hal yang menjadi perselisihan itu. Pembebanan yang berat sebelah berarti a priori menjerumuskan suatu pihak dalam kekalahan dan akan menimbulkan perasaan teraniaya pada yang dikalahkan itu.

Alat bukti dapat bersifat oral, documentary atau material. Alat bukti yang bersifat oral merupakan kata-kata yang diucapkan oleh seorang di persidangan, kesaksian tentang suatu peristiwa merupakan alat bukti yang bersifat oral. Termasuk dalam alat bukti yang bersifat documentary adalah surat. Sedangkan termasuk dalam alat bukti yang bersifat material adalah barang fisik lainnya selain dokumen. ${ }^{11}$ Termuat dalam H.I.R dalam Acara Perdata, hakim terikat pada alat-alat bukti sah yang berarti hakim hanya boleh mengambil keputusan berdasarkan alat-alat bukti yang ditentukan oleh undang-undang saja. Adapun alat-alat bukti dalam Hukum Acara Perdata yang disebutkan dlam pasal 1164 H.I.R. (Pasal 1866 Kitab Undang-undang Hukum Perdata) ialah : 1) Bukti Surat; 2) Bukti Saksi; 3) Persangkaan; 4) Pengakuan; 5) Sumpah.

\section{1) Bukti Surat}

Bukti tulisan berupa ini dalam perkara perdata merupakan bukti yang utama, karena dalam lalu lintas keperdataan sering orang dengan sengaja menyediakan suatu bukti yang dapat dipakai kalau timbul suatu perselisihan dan bukti yang disediakan tadi lazimnya berupa tulisan. Ada tiga macam surat sebagai alat bukti yaitu : 1) Surat biasa, 2) Akta otentik, 3) Akta dibawah tangan (Sutantio dan Oeriphartawinata). Perbedaan dari tiga macam surat ini yaitu dalam kelompok mana suatu tulisan termasuk, itu tergantung dari cara pembuatannya.

Sehelai surat biasa dibuat tidak dengan maksud untuk dijadikan bukti, apabila kemudian surat itu dijadikan bukti, hal itu merupakan suatu kebetulan

\footnotetext{
${ }^{10}$ Sunge, M. (2012). Beban Pembuktian dalam Perkara Perdata. Jurnal Inovasi, 9(02). Hal. 2.

${ }^{11}$ Sudikno Mertokusumo, Hukum Acara Perdata Indonesia, Penerbit Liberty, Yogyakarta, 1999, Hal.120
} 
saja, misalnya surat-surat sehubungan dengan korespondensi dagang, sedangkan akta dibuat dengan sengaja untuk dijadikan bukti. Dengan demikian maka unsur-unsur yang penting untuk suatu akta ialah kesengajaan untuk menciptakan suatu bukti tertulis dan penanda tanganan tulisan itu. Syarat penanda tanganan itu dapat dilihat pada pasal 1874 Kitab Undang-undang Hukum Perdata.

Akte otentik yaitu surat yang diperbuat oleh atau dihadapan pegawai umum yang berkuasa akan membuatnya, mewujudkan bukti yang cukup bagi kedua belah pihak dan ahli warisnya serta sekalian orang yang mendapat hak dari padanya, yaitu segala hal yang tersebut didalamnya surat itu dan juga tentang yang tercantum dalam surat itu sebagai pemberitahuan sahaja, tetapi yang tersebut kemudian itu hanya sekedar yang diberitahukan itu langsung berhubung dengan pokok dalam akte itu. Sedangkan suatu akta di bawah tangan yang berisikan suatu pengakuan berhutang karena telah menerima pinjaman sejumlah uang tunai, harus seluruhnya ditulis sendiri dengan tangan si penanda tangan atau setidaknya di bawah tertulis dengan tangannya sendiri suatu persetujuan mengenai jumlah uang tersebut, yang ditulis dengan huruf.

\section{2) Bukti Saksi}

Pembuktian dengan "saksi" dalam praktek lazim disebut "kesaksian". Dalam Hukum Acara Perdata, pembuktian dengan saksi sangat penting artinya terutama untuk perjanjian-perjanjian dalam hukum adat, yang pada umumnya karena saling percaya-mempercayai sehingga tidak dibuat sehelai suratpun. Kesaksian adalah kepastian yang diberikan kepada Hakim di persidangan tentang peristiwa yang disengketakan dengan jalan pemberitahuan secara lisan dan pribadi oleh orang yang bukan salah satu pihak dalam perkara, yang dipanggil di persidangan.

\section{3) Persangkaan}

Apabila dalam suatu pemeriksaan perkara perdata sukar untuk mendapatkan saksi yang dilihat, mendengar, merasakan sendiri, maka peristiwa hukum yang harus dibuktikan, diusahakan agar dapat dibuktikan dengan "persangkaan". "Persangkaan" ialah suatu kesimpulan yang diambil dari suatu peristiwa yang sudah terang dan nyata. Dari peristiwa yang terang dan nyata ini ditarik kesimpulan bahwa suatu peristiwa lain yanag harus dibuktikan juga telah terjadi. Ada dua macam persangkaan yaitu: (1) Persangkaan Hakim apabila yang menarik kesimpulan adalah Hakim. (2) Persangkaan Undang-undang ialah apabila yang menarik kesimpulan adalah Undang-undang. ${ }^{12}$

\section{4) Pengakuan}

Sebenarnya suatu pengakuan bukan suatu alat pembuktian, karena jika suatu pihak mengakui sesuatu hal, maka pihak lawannya dibebaskan dari kewajiban untuk membuktikan hal tersebut, sehingga dikatakan pihak lawan ini telah membuktikan hal tersebut. Sebab pemeriksaan di depan Hakim belum sampai tingkat pembuktian.

H.I.R. mengatur perihal "pengakuan” yaitu pasal 174 H.I.R. yang berbunyi:

\footnotetext{
12 R.Subekti, (2001). Hukum Pembuktian. PT. Pradya Paramita, Jakarta. Hal.45
} 
"Pengakuan yang diucapkan di hadapan Hakim, cukup menjadi bukti untuk memberatkan orang yang mengaku itu baik pengakuan itu diucapkan sendiri, baik dengan pertolongan orang lain, yang istimewa dikuasakan untuk melakukan itu. Pasal 175 H.I.R. : Maka diserahkan kepada pertimbangan dan waspadanya Hakim di dalam menentukan gunanya suatu pengakuan dengan lisan, yang dilakukan di luar hukum. Pasal 176 H.I.R. : Tiap-tiap pengakuan harus diterima segenapnya, dan Hakim tiada wenang akan menerima sebahagiannya saja dan menolak yang sebahagian lain, sehingga merugikan orang yang mengaku itu, yang demikian itu hanya boleh dilakukan kalau orang yang berutang, dengan maksud akan melepaskan dirinya, menyebutkan perkara yang terbukti tidak benar". Dalam Hukum Acara Perdata dikenal adanya 2 (dua) macam pengakuan yaitu: (1) Pengakuan yang dilakukan di depan sidang adalah pengakuan yang merupakan bukti yang mengikat dan sempurna. (2) Pengakuan di luar sidang pengadilan adalah pengakuan lisan dan tidak dapat dipakai selainnya dalam hal-hal dimana diizinkan pembuktian dengan saksi, sedangkan ketentuan pembuktian diserahkan kepada Hakim.

5) Sumpah

Sumpah pada umumnya adalah suatu pernyataan khidmat yang diberikan atau diucapkan pada waktu memberi janji atau keterangan dengan mengingat akan sifat Maha Kuasa dari pada Tuhan dan percaya bahwa siapa yang memberi keterangan atau janji yang tidak benar akan di hukum olehnya. Jadi pada hakekatnya sumpah merupakan tindakan yang bersifat religius yang digunakan dalam peradilan. Yang disumpah adalah salah satu pihak penggugat atau tergugat. Oleh karena itu yang menjadi alat bukti adalah keterangan salah satu pihak yang dikuatkan dengan "sumpah" dan bukan sumpah itu sendiri. Kita mengenal adanya dua macam "sumpah" yaitu :

a. Sumpah Promissoir adalah sumpah untuk berjanji melakukan atau tidak melakukan sesuatu, misalnya: sumpah saksi, dan sumpah (saksi) ahli. Dikatakan demikian karena sebelum memberikan kesaksian atau pendapatnya harus diucapkan pernyataan atau janji akan memberi keterangan yang benar dan tidak lain dari pada yang sebenarnya.

b. Sumpah Assertoir atau Confirmatoir adalah sumpah untuk memberikan keterangan guna meneguhkan bahwa sesuatu itu benar demikian atau tidak. Sumpah ini tidak lain adalah sumpah sebagai alat bukti, karena fungsinya adalah untuk meneguhkan (confirm) suatu peristiwa. Alat bukti sumpah ini diatur dalam H.I.R. (pasal 155, 158 dan 177).

Dengan demikian dapat disimpulkan bahwa hukum pembuktian dimaksud sebagai suatu rangkaian peraturan tata tertib yang harus diindahkan dalam melangsungkan peraturan di muka hakim, antara kedua belah pihak yang sedang mencari keadilan. ${ }^{13}$

Putusan hakim dalam pembangunan hukum meliputi tiga komponen utama, yakni materi (substansi), kelembagaan (struktur) dan budaya (kultur) hukum. Pembangunan hukum dilaksanakan melalui pembaharuan Hukum

${ }^{13}$ Sunge M, (2012). Op.Cit. 
dengan tetap memperhatikan kemajemukan tatanan hukum yang berlaku globalisasi. Kondisi demikian sebagai upaya untuk meningkatkan kepastian, kesadaran, pelayanan dan penegakan hukum yang berintikan keadilan, kebenaran, ketertiban dan kesejahteraan dalam rangka penyelenggaraan negara yang makin tertib dan teratur. ${ }^{14}$

Hakim, sebagai salah satu pejabat kekuasaan kehakiman yang melaksanakan proses peradilan, termasuk juga proses peradilan perdata, sudah tentu mempunyai tanggung jawab yang besar terhadap lahirnya putusan. Putusan yang dihasilkan oleh hakim di pengadilan idealnya tidak menimbulkan masalah-masalah baru di lingkungan masyarakat, artinya kualitas putusan hakim berpengaruh penting pada lingkungan masyarakat dan berpengaruh pada kewibawaan dan kredibilitas lembaga pengadilan itu sendiri. Kenyataan di lapangan masih banyak putusan hakim dalam proses peradilan yang justru menciptakan polemik baru dan tidak menyelesaikan masalah. Padahal idealnya putusan hakim yang dilahirkan tersebut harus mampu menyelesaikan perkara. Hakim, idealnya harus mampu melahirkan putusan yang mencerminkan kepastian hukum, keadilan dan kemanfaatan.

Hakim dalam menyelesaikan perkara perdata di pengadilan, mempunyai tugas untuk menemukan hukum yang tepat. Hakim, dalam menemukan hukum, tidak cukup hanya mencari dalam undang-undang saja, sebab kemungkinan undang-undang tidak mengatur secara jelas dan lengkap, sehingga hakim harus menggali nilai-nilai hukum yang hidup dalam masyarakat. ${ }^{15}$ Nilai-nilai hukum yang hidup dalam masyarakat tidak lain hukum adat dan hukum tidak tertulis. Hakim bertugas sebagai penggalinya dan merumuskannya dalam suatu putusan. Putusan hakim merupakan bagian dari proses penegakan hukum yang bertujuan untuk mencapai salah satunya kebenaran hukum atau demi terwujudnya kepastian hukum. Putusan hakim merupakan produk penegak hukum yang didasarkan pada hal-hal yang relevan secara hukum (yuridis) dari hasil proses secara sah di persidangan. Pertimbangan hukum yang dipakai oleh para hakim sebagai landasan dalam mengeluarkan amar putusan merupakan determinan dalam melihat kualitas putusan. ${ }^{16}$

Idealnya, dalam upaya menerapkan kepastian hukum, putusan hakim harus sesuai tujuan dasar dari suatu pengadilan, mengandung kepastian hukum sebagai berikut: pertama, melakukan solusi autoritatif, artinya memberikan jalan keluar dari masalah hukum yang di hadapi oleh para pihak (penggugat dan tergugat); kedua, efisiensi artinya dalam prosesnya harus cepat, sederhana, biaya ringan; ketiga, sesuai dengan tujuan undang-undang yang dijadikan dasar dari putusan hakim tersebut; keempat, mengandung aspek stabilitas yaitu dapat memberikan rasa tertib dan rasa aman dalam masyarakat; kelima, mengandung equality yaitu memberi kesempatan yang sama bagi pihak yang berperkara.

Semua perselisihan mengenai hak milik, "hak-hak perdata" (artinya hakhak yang berdasarkan "hukum perdata" atau "hukum sipil") adalah semata-mata

\footnotetext{
${ }^{14}$ Wantu, F. (2012). Mewujudkan Kepastian Hukum, Keadilan dan Kemanfaatan dalam Putusan Hakim di Peradilan Perdata. Jurnal Dinamika Hukum, 12(3), 479-489. Hal,480

${ }_{15}$ Muqaddas, B. (2002). Mengkritisi Asas-asas Hukum Acara Perdata. Jurnal Hukum Ius Quia Iustum, 20(9), 18-31. Hal, 21

${ }^{16}$ Alkostar, A. (2004). Fenomena-fenomena Paradigmatik Dunia Pengadilan di Indonesia (Telaah Kritis terhadap Putusan Sengketa Konsumen. Jurnal Hukum Ius Quia Iustum, 26(11), 1-14. Hal 1-2
} 
termasuk kekuasaan atau wewenang Hakim atau Pengadilan untuk menuntaskannya, dalam hal ini Hakim atau Pengadilan Perdata. Hakim atau Pengadilan ini merupakan alat perlengkapan dalam suatu negara hukum yang ditugaskan menetapkan hubungan hukum yang sebenarnya antara dua pihak yang terlibat dalam perselisihan atau persengketaan tadi. Hakim itu harus memutuskan atau menetapkan, bahwa memanglah saya adalah pemilik yang sah atas rumah yang saya diami itu, bahwa si pembeli barang sudah membayar lunas utangnya kepada si penjual, sehingga gugatan pihak yang terakhir ini untuk menuntut pembayaran harus ditolak, bahwa pihak penggugat adalah anak angkat dari si meninggal $\mathrm{X}$ dan berhak sebagian harta peninggalannya. Tugas Hakim atau Pengadilan sebagaimana di lukiskan di atas, adalah menetapkan hukum atau undang-undang secara khas ataupun menerapkan hukum atau undang-undang, menetapkan apa yang "hukum" antara dua pihak yang bersangkutan itu. Dalam sengketa yang berlangsung di muka hakim itu masingmasing pihak memajukan dalil-dalil (bahasa Latin "posita") yang saling bertentangan. Hakim harus memeriksa dan menetapkan dalil-dalil manakah yang benar dan dalil-dalil manakah yang tidak benar.

Kepastian hukum yang dituangkan dalam putusan hakim merupakan hasil yang didasarkan pada fakta-fakta persidangan yang relevan secara yuridis serta dipertimbangkan dengan hati nurani. Hakim selalu dituntut untuk selalu dapat menafsirkan makna undang-undang dan peraturan-peraturan lain yang dijadikan dasar untuk diterapkan. Penerapan hukum harus sesuai dengan kasus yang terjadi, sehingga hakim dapat mengkonstruksi kasus yang diadili secara utuh, bijaksana dan objektif. Putusan hakim yang mengandung unsur kepastian hukum akan memberikan kontribusi bagi perkembangan ilmu pengetahuan di bidang hukum. Hal ini disebabkan putusan hakim yang sudah mempunyai kekuatan hukum tetap, bukan lagi pendapat dari hakim itu sendiri yang memutuskan perkara, tetapi sudah merupakan pendapat dari institusi pengadilan dan menjadi acuan masyarakat dalam pergaulan sehari-hari. ${ }^{17}$

\section{SIMPULAN DAN SARAN}

Beracara dalam hukum acara perdata dapat dipakai dalam arti luas dan dalam arti sempit. Dalam arti luas beracara meliputi segala tindakan hukum yang dilakukan, baik di luar maupun di dalam sidang pengadilan guna menyelesaikan suatu perkara menurut ketentuan hukum acara perdata. Sedangkan dalam arti sempit, beracara meliputi tindakan beracara sesungguhnya di dalam sidang pengadilan sejak sidang pertama sampai dengan sidang terakhir hakim menjatuhkan putusannya. Untuk prosedur dalam pengajuan Gugatan di Pengadilan merujuk pada Pasal 118 ayat (1) Herizen Indlandsch Reglement ("HIR")/Pasal 142 RBg.

\footnotetext{
17 Wantu, F. (2012). Loc.Cit. Hal, 483
} 


\section{DAFTAR RUJUKAN}

Alkostar, A. (2004). Fenomena-fenomena Paradigmatik Dunia Pengadilan di Indonesia (Telaah Kritis terhadap Putusan Sengketa Konsumen. Jurnal Hukum Ius Quia Iustum, 26(11), 1-14.

Asfiyak, K., \& Muslim, M. (2020). Praktek Sidang Cepat Di Luar Aturan Hukum Acara Perdata Demi Efisiensi Penyelesaian Perkara Di Pengadilan Agama Kota Malang. Jurnal Ilmiah Ahwal Syakhshiyyah (JAS), 2(2), 4451 .

Dinata, I. W. W., \& Bagiastra, I. N. Cara Mengajukan Gugatan Dan Perubahan Gugatan Dalam Praktek Peradilan Hukum Acara Perdata. Kertha Negara: Journal Ilmu Hukum, 5(2).

Dwi Agustine (2017). Pembaharuan Sistem Hukum Acara Perdata. Jurnal RechtsVinding, 6(1), 1-7.

Hamzah, Y. A., Mangarengi, A. A., \& Buana, A. P. (2020). Analisis Yuridis Perkawinan Dibawah Umur Melalui Kewenangan Kantor Urusan Agama (Studi Kasus di KUA Kabupaten Bantaeng). PLENO JURE, 9(2), 119-128.

Ilyas, M. (2016). Eksekusi Tanah Terhadap Putusan Serta Merta. Jurisprudentie: Jurusan Ilmu Hukum Fakultas Syariah dan Hukum, 3(1), 63-72.

Ilyas, M., Razak, A., Aburaera, S., \& Bola, H. M. (2018). Supervision of Fair Execution for Civil Case Decision. JL Pol'y \& Globalization, 70, 101.

Nuna, M., \& Moonti, R. M. (2019). Kebebasan Hak Sosial-Politik Dan Partisipasi Warga Negara Dalam Sistem Demokrasi Di Indonesia. Jurnal Ius Constituendum, 4(2), 110-127.

Nyoman A. Martana, (2016). Hukum Acara Dan Praktek Peradilan Perdata, Fakultas Hukum Udayana.

Machmud, S. (2019). Konsep Strict Liability dalam Hukum Acara Perdata Indonesia. Jurnal Hukum Media Justitia Nusantara, 7(1).

Muqaddas, B. (2002). Mengkritisi Asas-asas Hukum Acara Perdata. Jurnal Hukum Ius Quia Iustum, 20(9), 18-31.

M Rasyid, L., \& Herinawati, H. (2015). Hukum Acara Perdata. Unimal Press.

R.Subekti, (2001). Hukum Pembuktian. PT. Pradya Paramita, Jakarta.

Sunge, M. (2012). Beban Pembuktian dalam Perkara Perdata. Jurnal Inovasi, $9(02)$.

Sudikno Mertokusumo, Hukum Acara Perdata Indonesia, Penerbit Liberty, Yogyakarta, 1999. 
Pleno Jure, Vol 10 (1), Oyaldi Dkk, Urgensi Beracara di Pengadilan...

Wantu, F. (2012). Mewujudkan Kepastian Hukum, Keadilan dan Kemanfaatan dalam Putusan Hakim di Peradilan Perdata. Jurnal Dinamika Hukum, 12(3), 479-489. 